\title{
KAJIAN KESETARAAN GENDER DAN PERLINDUNGAN ANAK TERHADAP KORBAN KECELAKAAN LALU LINTAS UDARA (Studi kasus pada Perempuan dan Anak pada Kecelakaan Pesawat Terbang Sriwijaya Air SJ 182)
}

\author{
Ratna Puspitasari, Urip Giyono \\ IAIN Syekh Nurjati Cirebon, Universitas Muhammadiyah Cirebon \\ ratnapuspitasari@syekhnurjati.ac.id,uripgiyono@gmail.com
}

\begin{abstract}
ABSTRAK
Salah satu moda transportasi yang diminati masyarakat di Indonesia karena menempuh jarak dan waktu yang lebih singkat adalah moda transportasi udara. Moda transportasi udara menempuh perjalanan dengan waktu yang lebih pendek dibanding dengan moda pesawat terbang di luar negeri. Meskipun memiliki resiko delay, terlambat dan kecelakaan yang berimbas pada kehilangan nyawa termasuk hilang sehingga dianggap penting masalah pengoperasian pesawat yang bertanggung jawab pada penumpang terutama pada perempuan dan anak. Perbedaan peran gender antara perempuan dan anak, dengan laki-laki mengakibatkan perbedaan pola perjalanan yang harus ditempuh melalui maskapai penerbangan. Hal ini menjadi penyebab perempuan dan anak sebagai kelompok yang rentan keselamatan pada setiap penerbangan misal: ibu hamil dan bayi. Pertanggungjawaban tersebut diatur dalam PPRI Nomor 40 Tahun 1995 terkait Angkutan Udara Pasal 45 ayat 1. UndangUndang Nomor 33 dan 34 Tahun 1964 menyebut bahwa pihak Jasa Raharja menyerahkan santunan pada pihak yang menghadapi kecelakaan pada saat meempuh perjalanan dalam menumpang angkutan umum dan korban kecelakaan lalu lintas jalan. Kecelakaan Sriwijaya Air SJ 182 pada tanggal 9 Januari Tahun 2021 rute Jakarta-Pontianak di Kepulauan Seribu melibatkan penumpang dan karyawan berjenis kelamin perempuan dan balita menarik minat penulis untuk melakukan riset terkait analisis kesetaraan gender, moda transportasi dan upaya perlindungan hukum terhadap perempuan dan anak dalam kasus kecelakaan Sriwijaya Air SJ 182 dengan teori struktural fungsional Parsons dan metode kualitatif dengan pendekatan studi kasus.
\end{abstract}

Kata Kunci: kesetaraan gender dan anak, perlindungan hukum, angkutan laut

\section{ABSTRACT}

One of the modes of transportation that is of interest to people in Indonesia because it covers a shorter distance and time is the air transportation mode. The air mode of transportation takes a shorter time than that of an airplane abroad. Even though it has the risk of delay, delay and accidents that have an impact on loss of life, including loss, it is considered important to issue aircraft operations which are responsible for passengers, especially women and children. The difference in gender roles between women and children and men results in differences in travel patterns that must be taken via airlines. This is the cause of women and children as a group that is vulnerable to safety on every flight, for example: pregnant women and babies. This accountability is regulated in PPRI Number 40 of 1995 regarding Air 
Transportation Article 45 paragraph 1.Law Number 33 and 34 of 1964 states that Jasa Raharja provides compensation to parties who face accidents while traveling on public transportation and victims of past accidents. cross road. The Sriwijaya Air SJ 182 accident on January 9, 2021, the Jakarta-Pontianak route in the Thousand Islands involving female passengers and employees and under-five attracted the author's interest to conduct research related to gender equality analysis, modes of transportation and legal protection efforts for women and children in cases Sriwijaya Air SJ 182 accident with Parsons functional structural theory and a qualitative method with a case study approach.

\section{Keywords: gender and child equality, legal protection, sea transportation}

\section{A.PENDAHULUAN}

Indonesia dikenal sebagai negara kepulauan sehingga sangat membutuhkan penerbangan yang menjadi sarana penting dalam menghubungkan 17. 508 pulau di seluruh nusantara dengan jumlah total populasi 255.000.000 jiwa. Dengan jumlah penduduk terbesar keempat di dunia, pertumbuhan kelas menengah serta berkembangnya penerbangan swasta bertarif murah pada dua dasawarsa terakhir maka Indonesia menjadi target pemasaran penerbangan yang berkembang pesat di Indonesia (Hartono, 1987). Peningkatan jumlah penumpang dari tahun 2009 (27.421.235) sampai 2014 (94.504.086) terhitung tiga kali lipat berbanding terbalik dengan permasalahan keselamatan penumpang yang kurang diperhatikan oleh pihak maskapai penerbangan. Indonesia memiliki 22 penerbangan komersial terjadwal dan carteran (Muhammad, 2007).

Deregulasi penerbangan memunculkan penerbangan baru seperti: Lion Air , Sriwijaya Air, Adam Air, Batavia Air, Adam Air, Batik Air, Nav Air, Air Asiadan Citilink (Syaifulloh, 2007). Maskapai berlomba memberi pelayanan prima meski beberapa konsumen sering melayangkan gugatan atas delay, kehilangan bagasi, manakala hak mereka diabaikan. Padahal perlindungan konsumen dibutuhkan dalam memberikan hak atas keselamatan, kenyamanan dan keamanan pada penumpang pesawat. Regulasi pemberian kompensasi pada penumpang akibat penundaan keberangkatanmenunjukkan detail hak yang terjcantum dalam perjanjian tiket. Penerbangan juga mengatur hak-hak yang dimiliki penumpang yang sakit dan difabel (Muhammad, 1998). 
Pasal 134 UU Penerbangan menunjukkan banyak hak penumpang yang harus dipenuhi pihak maskapai. Pada Konvensi Guandalajara 1961, pengangkut udara disebut contracting carier and actual carier. Contacting Carier adalah" a person who as principal makes an agreeman for carriage governed by the Warsaw Convention with passengger on consignor or with a person on behalf of the passengger or consignor. Contracting carier adalah pengangkut yang melakukan perjanjian dengan penumpang maupun pengirim ekspedisi di mana pengangkut udara merupakan setiap pihak yang melakukan perjanjian pengangkutan dengan pihak penumpang atau pengirim atau penerima barang, perjanjian yang berbentuk dokumen angkutan udara niaga atau komersial, pengangkut adalah perusahaanperusahaan penerbangan atau maskapai penerbangan (Adisasmita, 2012).

Dunia penerbangan di Indonesia mengenal dua istilah yaitu kejadian (incident) dan kecelakaan (accident). Incident merupakan peristiw selama penerbangan dilaksanakan terkait dengan operasi pesawat udara yang memiliki kemungkinan dapat membahayakan keselamatan selama penerbangan. Accident sebagai peristiwa di luar kemampuan manusia yang terjadi selama berada dalam perjalanan moda transportasi udara dari awal pemberangkatan sampai ke tempat tujuan yang berdampak pada kerugian, luka parah, sampai pada kematian yang menimbulkan kerusakan struktural yang disebabkan oleh human error, mesin (amchine technical) dan cuaca (weather).

Kasus kecelakaan Sriwijaya Air sangat menarik untuk dianalisis dalam kajian kesetaraan gender, moda transportasi serta pelindungan hukum pada perempuan dan anak yang menjadi korban kecelakaan Sriwijaya SJ 182 karena kesetaraan maupun keadilan gender bukan hanya penting dari aspek moralitas namun sangat penting dan relevan dalam kajian moda transportasi udara. Konvensi Internasional terkait Penghapusan Seluruh Diskriminasi pada Perempuan (CEDAW tahun 1979) menyebut bahwa diskriminasi terhadap perempuan adalah perlakuan yang beda, pembatasan berdasarkan jenis kelamin yang bertujuan mengurangi pengakuan termasuk perempuan dan anak korban kecelakaan. Diskriminasi terhadap gender perempuan dan anak muncul dalam bentuk stereotype atau pelabelan negatif, 
subordinasi atau posisi lemah dan marjinalisasi (peminggiran) menjadi hal dapat terjadi pada siapapun korban kecelakaan pada moda transportasi udara. Di sisi lain, analisis terhadap kasus hukum beberapa diantaranya mengandung unsur diskriminatif terhadap perempuan dan anak. Meliputi aspek materi hukum (content of law) budaya hukum (culture of law) dan struktur hukum (structure of law) (Neufville, 2003).

Perjanjian pengangkutan telah berpedoman pada pasal-pasal bagian umum hukum perjanjian Burgerlijk Wetboek (KUH Perdata), meskipun demikian undang-undang telah diputuskan beragam peraturan khusus yang memiliki tujuan membatasi kepentingan umum terhadap kebebasan dalam menyusun perjanjian pengangkutan yaitu dengan membebankan kewajiban khusus pada pihak maskapai selaku pengangkut sebagai hal yang wajib dalam sebuah perjanjian (Adisasmita, 2012). Negara berperan mengatur kepentingan-kepantingan itu menjadi selaras dan harmonis dan berwenang dalam mengatur dan turut serta menghadapi celah-celah pelanggaran dengan menyiapkan rangkaian perangkat peraturan yang ketat dan member sanksi jika terjadi pelanggaran (Sidabalok, 2006).

Aspek kesetaraan gender dikaji Fakih dalam Sudjatmoko (2011) yang menjelaskan gender sebagai penggolongan secara gramatikal terhadap kata-kata dan kata-kata lain yang berkaitan dengannya yang secara garis besar berhubungan dengan keberadaan dua jenis kelamin atau kenetralan. Sejak tahun 1990 an, perempuan dan laki-laki memiliki kebutuhan yang berbeda pada transportasi dan secara umum intervensi di bidang transportasi kurang mampu menjawab kebutuhan penumpang berjenis kelamin perempuan. Ada empat faktor yang berpengaruh pada perbedaan laki-laki dengan perempuan dalam penggunaan moda transportasi udara yaitu: faktor ekonomi, sscial, perbedaan fisik, termasuk kekuasaan dan kerentanan dan psikologis (Hamilton, 2005). Kaitannya dengan moda transportasi udara adalah bahwa perbedaan peran gender ternyata menimbulkan perbedaan pola perjalanan. Pola perjalanan perempuan dan anak seringkali melakukan perjalanan di hari sibuk dan jam sibuk (peak hours), 
menempuh jarak perjalanan lebih pendek dan menghindari perjalanan pada saat malam hari. Perbedaan pola perjalanan dan sumber daya keuangan yang dimiliki sangat mempengaruhi pemilihan moda transportasi dimana perempiuan cenderung menggunakan moda transportasi umum (Yanti, 2002).

Berdasar kerentanan atau resiko, perempuan dan anak-anak secara fisik lebih rentan terhadap kecelakaan dibandingkan penumpang laki-laki. Di samping itu laki-laki dan perempuan mempunyai nilai-nilai budaya yang berbeda terkait dengan jenis moda transportasi udara. Perempuan cenderung lebih tertarik moda transportasi umum yang dianggap lebih aman, murah dan mempermudah mereka dalam melakukan perjalanan sebaliknya laki-laki cenderung lebih menyukai perjalanan dengan menggunakan kendaraan pribadi (Caplan, 1987).

Sriwijaya Air sebagai bagian dari pihak penyelenggara pelayanan angkutan umum berstandar baik karena telah memenuhi standar-standar yang telah ditetapkan pemerintah maupun dunia penerbangan internasional. Khisty (1998) menyebut keputusan dalam pemilihan moda lebih berdasarkan pertimbangan beberapa faktor diantaranya pertimbangan beberapa hal diantaranya adalah sebagai berikut: jarak, waktu, biaya, keamanan, kenyamanan dan efisiensi. Data penumpang menunjukkan mayoritas adalah pelanggan tetap anak perusahaan Garuda ini.

Choice user merupakan kelompok pelaku perjalanan dengan banyak pilihan yaitu menggunakan kendaraan pribadi atau angkutan umum. Di sisi lain, captive user merupakan kelompok pelaku perjalanan disebabkan oleh karena kendalakendala berupa aspek fisik, aspek hukum dan ekonomi. Teori Struktural Fungsional Parsons, spesifikasi pada Sosiologi Perlindungan terhadap perempuan dan anak menjadi dasar bagi penulis dalam menyoroti terselenggaranya harmonisasi keadilan dan kesetaraan oleh sebab itu, sebab hukum selayaknya berkeadilan dan sensitif gender agar terjamin hak asasi perempuan dan anak. Pada dasarnya UU No. 1/74 dan UU No. 23/2002 secara normatif mampu melindungi anak-anak. Hal ini dikuatkan oleh Undang Undang No. 39 tahun 1999 tentang HAM yang mengatur perlindungan anak. 
Grand theory Struktural Fungsional Talcott Parsons menjelaskan perubahan masyarakat tradisional pada masyarakat modern disertai proses diferensiasi integrasi. Parsons menyebut fungsi utama sebuah sistem hukum yaitu melaksanakan fungsi integratif melalui cara pengendalian bagian-bagian yang menjadi komponennya. Namun demikian, dalam menjalankan fungsi tersebut, tidak selamanya hukum bersifat otonom sehingga hanya mampu melaksanakan fungsinya dengan tepat dan jika memperoleh pengarahan dari sub sistem budaya yang memberi masukan terkait nilai-nilai yang ditunjang oleh hukum dalam melaksanakan fungsi integrasi (Giddens, 1984). Pertama, masyarakat dianalisis sebagai sebuah kesatuan utuh yang terdiri beragam bagian yang saling berinteraksi, kedua, hubungan yang ada bersifat timbal balik, ketiga, sistem sosial bersifat dinamis di mana penyesuaian tidak mengubah sistem sebagai kesatuan yang utuh, keempat, integrasi sempurna pada masyarakat yang sesungguhnya belum pernah ada sehingga menimbulkan satu kesatuian yang utuh yang dinetralisir melalui proses pelembagaan, kelima, pelembagaan berjalan secara gradual dan menjadi proses adaptasi dan penyesuaian, keenam, perubahan sebagai hasil adaptasi dari luar yang tumbuh sebab diferensiasi dan inovasi, ketujuh, sistem terintegrasi melalui pemilikan nilai-nilai yang sama. Teori sosiologi Parsons dalam penyelesaian tanggung jawab terhadap korban kecelakaan lalu lintas Sriwijaya Air SJ 182 .As Toot As Social Engineering digunakan untuk menggerakkan kemampuan sosial masyarakatdalam mewujudkan suatu peraturan hukum yang dapat memberikan rasa keadilan dan kesejahteraan bagi masyarakat.

Selanjutnya, Teori Friedman tentang sistem hukum (legal system) berupa seperangkat aturan atau norma-norma perilaku baik secara tertulis maupun tidak (legal substantive), dan sebgai struktur atau lembaga yang menjalankan proses hukum (legal stucture) serta sebagai budaya hukum (legal culture). Sebagai bagian dari sistem sosial, sistem hukum menghasilkan: pertama, mewujudkan harapan masyarakat, kedua, menyediakan skema normatif yaitu menyediakan mekanisme dan tempat sehingga kasus terselesaikan, dan ketiga, sistem hukum 
mampu menjadi kontrol sosial, dan keempat, mampu menjadi instrumen perubahan tatanan sosial dan rekayasa (Giddens, 1984).

Penelitian ini mencoba mengupas sejauh mana kajian aspek kesetaraan gender terhadap moda transportasi udara dalam perlindungan hukum yang diberikan pada perempuan dan anak korban kecelakaan pesawat udara, dalam hal ini adalah studi kasus pada kecelakaan udara Sriwijaya Air SJ 182.

\section{B. METODE PENELITIAN}

Penelitian ini menggunakan metode penelitian kualitatif melalui pendekatan studi kasus dengan proses pengujian keakuratan data terkait kecelakaan Sriwijaya 182 melalui teknik triangulasi data yaitu triangulasi sumber, triangulasi peneliti dan triangulasi teori. Studi kasus (case study) ini memiliki ciri kualitatif dengan kunci risetnya memungkinkan untuk mengamati suatu peristiwa atau situasi terjadi (Hodgetts dan Stole, 2003) yang menyebut bahwa studi kasus individu, kelompok, komunitas membantu mengarahkan segala sesuatu yang penting sebagai sasaran perhatian, proses sosial kemasyarakatan dalam peristiwa nyata, pengalaman pemegang kebijakan.

Kasus kecelakaan Sriwijaya 182 mampu mengilustrasikan bagaimana masalah dapat diatasi melalui penelitian. Sebagai metode penelitian yang fleksibel, menarik dan sangat umum digunakan dalam ilmu sosial, penelitian studi kasus belum memiliki standarisasi atau formula bagaimana melaksanakan penelitian (Yin, 2002). Yin (2002) mendefinisikan studi kasus sebagai proses penelitian. "A case study is an empirical inquiry that investigates a contemporary phenomenon (the 'case) within its real-lifecontext, especially when the boundaries between phenomenon (the case) within its real-life context, may not clearly evident”. Penelitian studi kasus bertujuan menguji pertanyaan termasuk masalah penelitian terkait antara fenomena maupun konteks di mana fenomena itu terjadi.

Studi Kasus Sriwijaya 182 digunakan dengan pertimbangan pertama, fokus penelitian menjawab pertanyaan bagaimana dan mengapa, kedua, peneliti tidak mampu memanipulasi perilaku pihak-pihak yang terlibat dalam penelitian, ketiga, belum ada batasan yang jelas terkait fenomena dan konteks. Peneliti studi kasus 
berfokus pada kasus kecelakaan pesawat Sriwijaya 182 secara mendalam sehingga dapat dikenali, khas dan unik. Penelitian studi kasus ini terdiri atas penelitian yang sangat rinci, sehingga data yang dikumpulkan dalam periode Januari sampai Februari dengan fenomena kesetaraan dan perlindungan hukum terhadap perempuan dan anak korban kecelakaan Sriwijaya Air SJ 182 bertujuan memberi analisa tentang konteks tertentu dan proses yang berhubungan dengan isu teoritis struktural fungsional Parsons yang sedang dikaji. Fenomena tersebut tidak dapat dipisahkan dengan konteksnya namun menjadi menarik saat tujuan memahami perilaku yang dipengaruhi konten tertentu (Hartley, 2004).

\section{C.HASIL DAN PEMBAHASAN}

\section{Aspek Kesetaraan Gender pada Perempuan dan Anak Dalam Kecelakaan}

\section{Pesawat}

Maskapai penerbangan Sriwijaya menjadi bagian dunia bisnis terikat dalam perikatan yang timbul disebabkan Undang-Undang diatur dalam pasal 1320 KUHP yang menjelaskan sahnya perjanjian pihak maskapai dengan penumpang adalah apabila ada kesepakatan antara pihak yang melakukan perjanjian, cakap menyusun perjanjian, mengenai hal tertentu dan memiliki sebab yang halal. Hukum perjanjian mengacu pada asa kebebasan berkontrak dalam pasal 1338 KUH Perdata. Hasil survey di lapangan menunjukkan dalam penyerahan kompensasi tidak menimbulkan sengketa karena pihak maskapai bertanggung jawab secara hukum berawal dari terjadinya perikatan yang melahirkan hak dan kewajiban pada korban maupun keluarganya. Pasal 1233 KUH Perdata bertanggung jawab atas keselamatan penumpang sebagaimana yang terjadi dalam kasus kecelakaan pesawat terbang Sriwijaya Air 182, tidak ditemukan penumpang yang secara sadar melakukan pelanggaran hukum keselamatan penerbangan dengan melakukan tindak pidana udara namun ditemukan 2 penumpang yang memanfaatkan tiket atas nama orang lain.

Ganti rugi penumpang yang seluruhnya meninggal diserahkan pada ahli waris penumpang (suami/istri, anak, atau orang tua) dengan mengacu Hukum angkutan udara yang mengatur tuntutan hak penumpang terkait perlindungan 
konsumen. Pasal 3 Permenhub menyebut penumpang meninggal dunia pada pesawat udara disebabkan kecelakaan Rp. 1.250.000.000. Ganti rugi Rp. 500.000.000 diserahkan pada ahli waris penumpang meninggal dunia

\section{Sistem Tindakan dalam Struktural Fungsional Kasus Sriwijaya Air}

Kecelakaan pesawat terbang pada penerbangan tanggal 10 Januari 2021 mengakibatkan kerugian yang harus ditanggung oleh pihak penumpang maupun pihak maskapai dan terutama paling berimbas pada persoalan hukum terutama tanggung jawab yang dibebankan pada pihak maskapai atau pengangkut (carrier) pada penumpang serta pemilik barang yang menjadi bagian dalam perjanjian dalam pengangkutan penerbangan maupun sebagai konsumen (Rosadi, 2008). Perangkat peraturan penerbangan Sriwijaya 182 memiliki bertujuan: pertama, menjaga equalitas pihak-pihak berkepentingan, kedua memberi sanksi atau hukuman jika timbul sengketa dengan cara menegakkan peraturan yang telah diberlakukan, ketiga, mediator beserta hukum acara yang berlaku. Model perlindungan pada penumpang meliputi: pertama memformulasikan perlindungan konsumen legislasi atau undangundang, kedua, melakukan pendekatan secara menyeluruh atau holistik, yakni bahwa secara khusus terdapat undang-undang yang mengatur persoalan perlindungan konsumen, termasuk menjadi pelindung bagi undang-undang sektoral dalam sudut pandang penumpang maupun ahli warisnya.

Dalam hukum pengangkut ada 3 item tanggungjawab pengangkut diantaranya adalah: pertama, prinsip tanggung jawab berdasar kelalaian atau the based on fault/liability based on Fault Principle, Kedua, pertanggungjawaban berorientasi praduga (rebuttable presumption of liability principle, ketiga, pertanggungjawaban mutlak atau no fault, atau strict liability, absolute liability principle). Dilihat dari segi wilayah operasi penerbangan, Sri Wijaya Air termasuk bagian penerbangan domestik (nasional), yaitu penerbangan antar pelabuhan udara di wilayah Indonesia dengan memakaii pesawat udara yang beregristrasi Indonesia.

Jurnal Edueksos Vol. X, No. 1, Juni 2021

The journal of social and economic education 


\section{Aspek-Aspek Perlindungan Perempuan dan Anak dalam Kasus Sriwijaya}

Air

Perlindungan menurut istilah Inggris 'protection' bermakna pertama protecting or being protected, kedua system protecting, ketiga person or thing that protect. Jadi perlindungan memiliki tiga unsur yaitu tindakan melindungi, adanya pihak dan cara melindungi. Perlindungan terhadap konsumen diberikan oleh hukum karena mampu mengakomodir beragam kepentingan konsumen, memiliki daya paksa, bersifat permanen, konstitusional yang diakui dan ditaati masyarakat (Harvey, 1986).

Cara perlindungan terhadap penumpang Sriwijaya 182 dilakukan melalui beberapa cara, pertama menyusun peraturan (by giving regulation) dengan tujuan memberi hak dan kewajiban dan penjaminan hak subyek hukum, kedua menegakkan peraturan (by the law enforcement) melalui hukum adminstrasi negara dengan fungsi mencegah (preventif) pelanggaran hak-hak konsumen melalui perijinan dan pengawasan, hukum pidana dengan fungsi menanggulangi (represive) pelanggaran peraturan perundang-undangan dengan memberi sanksi hukum pidana, hukum perdata berfungsi mengembalikan hak (curative, recovery) dengan ganti rugi sesuai pasal 2 UU no 8 Tahun 1999, meliputi aspek keselamatan penerbangan, keamanan penerbangan, kenyamanan selama penerbangan, pelayanan, penentuan tarif atau ongkos penerbangan, perjanjian angkutan udara, pengajuan klaim, dan perlindungan melalui asuransi.

\section{Kesetaraan Gender terhadap Perempuan dan Anak}

Tiap penumpang Sriwijaya 182 memiliki hak untuk memperoleh rasa aman serta bebas dari diskriminasi. Sebelum peristiwa yaitu pada saat pembelian tiket, pemilihan tempat duduk, pelayanan optimal sampai peristiwa dan pasca kecelakaan memperoleh perlindungan dari keluarga, advokat, lembaga sosial, kepolisian, kejaksaan, pengabdian atau pihak lain agar jenasah mereka segera ditemuka, diidentifikasi melalui tes DNA, mengamankan, 
menyelamatkan barang maupun identitas pribadi yang masih tertinggal dalam jangka waktu yang ditentukan oleh KNKT.

Perlindungan hukum pada perempuan dan anak bukan hanya melalui undang-undang yang mengatur perlindungan pada perempuan maupun anak secara nyata melalui bantuan hukum pada korban maupun ahli waris, lembaga swadaya masyarakat yang mengurus tindak lanjut kecelakaan pesawat, serta pemberian keadilan yang hak-haknya tidak diakui. Pasal 1 UU No. 7 tahun 1984 menjelaskan tentang Pengesahan Konvensi Penghapusan Segala Bentuk Diskriminasi terhadap Wanita/Perempuan termasuk pasal 17 Undang-Undang No. 39 Tahun 1999 terkait hak asasi individu adalah salah satu alasan perlunya perempuan dan anak termasuk 2 bayi mendapat perlindungan hukum secara adil diantaranya penanganan khusus maskapai. Dalam penerbangan domestik, Sriwijaya 182 memberlakukan peraturan bahwa bayi dapat bepergian dengan tiket orang tua atau wali dengan dipangku namun jika mereka memerlukan kursi sendiri, bayi harus dipesankan tiket . Keranjang bayi dapat diminta saat chek in sesuai ketersediaan. Bagi anak-anak wajib membeli tiket pesawat atas nama dirinya. Keamanan anak mengalami peningkatan saat mereka menggunakan kursi anak. Pemesanan kursi dapat dilakukan dalam kurun waktu maksimal 7 hari sebelum penerbangan dilakukan. Hak anak dalam penerbangan juga meliputi makanan dengan melakukan pemesanan serta pemberitahuan alergi dan persyaratan khusus yang dimiliki anak.

Orang tua atau penumpang yang membawa bayi di bawah 2 tahun diperbolehkan menyediakan makanan tersendiri selama penerbangan, sementara itu maskapai menyediakan rangkaian terbatas makanan bayi seperti: susu, botol bayi, sereal, dan roti kering. Penumpang yang bepergian dengan bayi maupun anak-anak diijinkan membawa produk cairan, aerosol maupun gel dalam jumlah yang sesuai kebutuhan bagi bayi dan balita sesuai dengan batas kewajaran yang ditentukan oleh petugas pemeriksaan keamanan bea dan cukai (Rosmawti, 2013). Dalam aspek kesehatan, perempuan dan anak yang ikut dalam penerbangan selayaknya memiliki imunisasi yang dibutuhkan sebelum 
tanggal keberangkatan diantaranya obat dan resep untuk mengantisipasi keselamatan dalam penerbangan termasuk sertifikat laporan obat-obatan dokter yang diperlukan telah dilaksanakan secara baik, benar, terstruktur dan terkoordinasi oleh semua pihak terkait (negara, masyarakat baik perorangan maupun kelembagaan).

Bentuk perlindungan hukum pada perempuan termasuk anak-anak korban kecelakaan Sriwijaya Air 182 diantaranya adalah sebagai berikut: bahwa pada dasarnya, perempuan dan anak memiliki hak-hak atas ketentuan peraturan perundang-undangan di Indonesia yang mengatur hak-hak manusia yaitu pada pihak maskapai termasuk hak-hak perempuan dan anak diartikan bahwa tempat berlindung atau ketentuan peraturan perundang-undangan di Indonesia telah dilaksanakan oleh pihak maskapai penerbangan Sriwijaya secara baik, benar, terstruktur dan telah terkoordinasi semua pihak dari pelayanan selama penerbangangan, proses pencarian dan identifikasi korban saat kecelakaan sampai 3 minggu pasca kecelakaan bahkan sampai pemakaman dan ganti rugi sesuai dengan aturan yang telah ditentukan (Rosmawati, 2013).

Kendala yang dihadapi dalam kecelakaan Sriwijaya Air 182 dari segi kebijakan tersentral meliputi pembatasan waktu pencarian dikeluhkan oleh pihak keluarga korban, akses masuk ke lokasi hilangnya pesawat terkendala angin dan cuaca yang buruk serta lamanya proses identifikasi DNA bahkan proses akhir yaitu pemakaman. Di sisi lain dari segi struktur hukum, kendala utama adalah aparat penegak hukum masih menggunakan peraturan lama, aparat hukum belum memanhami Undang-Undang, interpretasi yang berbeda antar aparat penegak hukum. Perlindungan hukum terhadap penumpang maskapai diantaranya adalah pertama KUH Perdata, kedua Ordonansi Penerbangan tahun 1939 serta OPU 1939 ketiga UU No 1 tahun 2009 mengenai penerbangan beserta peraturan pelaksanaannhya, keempat, UU No 8 tahun 1999 melalui Indische Staatblad 1939 No. 100. Secara formal, Indonesia masih memakai OPU 1939 yang menjadi dasar hukum pengangkutan udara domestik. 


\section{KESIMPULAN}

Peristiwa yang dialami Sriwijaya Air 182 menunjukkan bahwa moda transportasi netral gender karena layanan maupun infrastruktur transportasi dianggap sesuai bagi semua orang berjenis kelamin laki-laki maupun perempuan meski bukti statistik menunjukkan bahwa penggunaan moda transportasi antara laki-laki dengan perempuan secara kuantitatif sering tejadi buta gender atau bias gender. Perjanjian moda angkutan transportasi udara maskapai penerbangan Sriwijaya menerapkan prinsip tanggung jawab atas dasar kesalahan atau memiliki kesalahan (liability based on fault or negligence atau fault liability) ssehingga kerugian yang ditanggung penumpang korban kecelakaan memperoleh santunan atau kompensasi tanpa melihat motivasi atau tujuan dari si penyebab kerugian. Bentuk-bentuk penyampaian komunikasi krisis dilakukan melalui press conference, press release, freeding information serta Crisis Management Centre.

Kecelakaan pesawat Sriwijaya Air 182 dapat dikualifikasikan sebagai accident sebagaimana tercantum dalam Pasal 17 Konvensi Warsawa 1929 sehingga menjadi kejadian yang unsual atau tidak terprediksi sebelumnya (unexpected). Pihak maskapai penerbangan Sriwijaya Air telah mempertanggungjawabkan kerugian kepada ahli waris korban 54 orang penumpang dan 6 awak pesawat sesuai dengan ketentuan pasal 21 Ayat (1) Konvensi Montreal 1999 dalam bentuk uang meskipun dukungan ekonomi terhadap ahli waris maupun keluarga tidak mapu mengembalikan korban kepada keluarga. Startegi respon krisis meliputi strategi korban, pengurangan, pembangunan kembali (rebuild) dengan memperlakukan korban secara lebih baik dengan jaminan reputasi maskapai Sriwijaya.

\section{REFERENCES}

Adisasmita, S.A. 2012. Penerbangan dan Bandar Udara. Yogyakarta: Graha Ilmu Ali, Achmad. 2009. Menguak Teori Hukum dan Teori Peradilan. Jakarta: Kencana AZ, Nasution Z. 1999. Pengantar Hukum Perlindungan Konsumen. Jakarta: Daya Widya

Caplan, 1987. Cultural Construction of Sexuality. London: Tavistock Publication. 
Carson, SH., dan Langer E.J (2006). Mindfulness and Self-Acceptance. Journal of

Rational-Emotive \& Cognitive-Behavior Therapy, 24(1) dan 29-4

Cope, D, 2015. Case Study Research Methodology in Nursing Reseach. Oncology Nursing doi: 10.14710/jpu.12.2.164-175

De Neufville, 2003. Airport Aystems: Planning, Design and Management, Mc Graw Hill.

Ekawati, 2014. Kajian Dampak Pengembangan Pembangunan Kota Malang terhadap Kemacetan Lalu Lintas (Studi pada Dinas Perhubungan Kota Malang. Jurnal Administrasi Publik 2 (1), 129-133

E. Syaifullah, Artikel Dilema Penerbangan Kita.(wwwunisba.co.id: diakses tanggal 7 Juni 2007

Fakih, Mansour. (1999) Analisis dan Transformasi Sosial. Yogyakarta: Pustaka Pelajar.

Giddens, Antony. 1984. The Constitutionof Society: The out line of The Theory of Structuration. Cambridge: Polity Press

Gunawan Widaja dan Ahmad Yani, 2003. Hukum tentang Perlindungan Konsumen, (Jakarta: PT Gramedia Pustaka Utama) Hal ix

Hadisaputro, Hartono. 1987. Pengangkutan dengan Pesawat Udara . Yogyakarta: UII Press

Haedar, Akib. 2008. Artikulasi Konsep Implementasi Kebijakan, Perspektif Model dan Kriteria Pengukurannya. Jurnal Keb9ijakan Publik.

Harly, Rosadi. 2008. Fasten Your Seat Belt (Panduan Keselamatan dan Kenyamanan Terbang bagi Penumpang. Jakarta: PT Elex Media Komputindo.

Harvey, G, 1986. Study of Airport Acces Mode Choice, Journal of Transportation Enggineering.

Hendarto, Sri. 2001. Dasar-dasar Transportasi. Bandung: Institut Teknologi Bandung.

Hollows, Joanne. 2000. Feminism, Feminity and Popular Culture. London: Manchester University Press.

Indrayani, H. (2017). Etika Advokasi Public Relations dalam Manajemen Krisis Reputasi. Interaksi: Jurnal Ilmu Komunikasi. Vol 5 No. 1 Hal: 68-77.

Janus Sidabalok, 2006, Hukum Perlindungan Konsumen di Indonesia, (Bandung: PT Citra AdityaBakti) hal. 6.

Jimly Asshiddiqie, Gagasan Negara Hukum Indonesia; Sebuah Makalah lepas; Lihat http://www.jimly.com/makalah/namafile/135/Konsep Jimly Asshiddiqie; Gagasan Negara Hukum Negara Hukum Indonesia.pdf

Komnas Perempuan (2019). Catatan Tahunan Kekerasan terhadap Perempuan 2019 dari https://www.komnasperempuan.go.id/read-news-catatan -tahunankekerasan-terhadap - perempuan-2019g

Lembaran Negara RI Tahun 1999 Nomor 42, Tambahan Lembaran Negara Nomor 3821.

Jurnal Edueksos Vol. X, No. 1, Juni 2021

The journal of social and economic education 
M. Ali Mansyur, 2007. Penegakan Hukum tentang Tanggung Gugat Produsen dalam Perwujudan Perlindungan Konsumen. (Yogyakarta: Penerbit Genta Press) Hal.81.

Martono, K, 2007. Pengantar Hukum Udara Nasional dan Internasional (Jakarta: Grafindo Persada).

Mediansyah, Achmad Risa, 2017. Jaringan Kebijakan Publik Implementasi

Kebijakan Transportasi di Kota Makassar. Jurnal Analisis dan Kebijakan Publik 3(1), 14-22

Merrriam, S.B. 2009. Qualitative Research A Guide to Design and Implementation, San Fransisco, CA : Jossey-Bass

Muhammad, Abdulkadir, 1998. Hukum Pengangkutan Niaga. Bandung: Penerbit Citra Aditya Bhakti.

Muhammad, Abdulkadir , 2007. Arti Penting dan Strategis Multimoda Pengangkutan Niaga di Indonesia dalam Perspektif Hukum Bisnis di Era Globalisasi Ekonomi . Yogyakarta: Genta Press.

Muhtar, Yanti, 2002. Pendidikan Berperspektif Keadilan Gender. Jakarta: Depdiknas.

Nasution, 2003. Metode Research. Jakarta: PT Bumi Aksara.

Prayudi, P. (1998). Strategi Komunikasi Organisasi dalam Menghadapi Krisis. Paradigma: Jurnal Masalah Sosial, Politik dan Kebijakan. Vol 2 No. 6. Hal: 31-42.

Putri, E.H. 2013. Evaluasi Kebijakan Peremajaan Angkutan Kota dalam Upaya Peningkatan Pelayanan Publik (Studi pada Dinas Perhubungan Kota Malang). Jurnal Administrasi Publik, 1(3), 87-93

Rahimudin (2015). Analisis Faktor-Faktor Penyebab Kecelakaan Pesawat Udara Komersil di Indonesia pada Tahun 2002 sampai dengan Tahun 2012. Jurnal Manajemen Dirgantara, 8(12): 1-12

R. Subekti, 1995. Aneka Perjanjian. (Bandung: PT Citra Aditya), Hal.69

Ridwan Khairandy, 2006. Tanggung Jawab Pengangkut dan Asuransi Tanggung jawab sebagai Instrumen Perlindungan Konsumen Angkutan Udara, (Jakarta: Jurnal Hukum Bisnis 25) hal 20-21

Rosmawati, 2013. Tesis. Tanggung Jawab Perusahaan Penerbangan terhadap Penumpang atas Kerugian Akbat Kejahatan Penerbangan (Hijacking) menurut Hukum Nasional dan Internasional. Bandung: FH UNPAD

Rustian, Kamaluddin, 2003. Ekonomi Transportasi Karakteristik, Teori dan Kebijakan. Jakarta: Ghalia.

Sasongko, Sundari S. 2009. Konsep dan Teori Gender. Jakarta: BKKBN

Savitri, Niken, 2008. HAM Perempuan, Kritik Teori Hukum Feminis terhadap KUHP, Bandung: Refika Aditama. 
Sagala, R. (2015). Strategi Komunikasi Public Relations Lion Air dalam Menghadapi Krisis Delay Berkepanjangan di Bandara Soekarno Hatta. (2015). Jurnal Fessospol Jendela. Vol 3 No.2 Halaman 47-57

Sari, E.P., \& Nuryoto, S (2002). Penerimaan Diri pada Lanjut Usia Ditinjau dari Kematangan Emosi. Jurnal Psikologi, 2, 73-88

Sharma, H.L., \& Rani R. (2013). Relationship of Personal Growth Initiative with Self-Efficacy among University Postgraduate Students. Journal of Education and Practice, 4(16), 125-135.

Soegijatna Tjakranegara, 1995. Hukum Pengangkutan Barang dan Penumpang. Jakarta: Lem,baga Penerbit FEUI, hal 5.

Statistik, B.P. 2016. Lalu Lintas Penerbangan Indonesia 2003-2016. Jakarta: tanpa penerbit

Suriatmadja, Thohir Toto. 2005. Pengangkutan kargo Udara. Bandung: Pustaka Bani Quraisy

Sution Usman Adji, 1991. Hukum Pengangkutan di Indonesia. Jakarta: PT Rineka Cipta, hal. 1.

Undang-Undang Nomor 33 Tahun 1964 tentang Dana Pertanggungan Wajib Kecelakaan Penumpang

Undang-Undang Nomor 15 Tahun 1992 tentang Penerbangan

Undang-Undang Nomor 8 Tahun 1999 tentang Perlindungan Konsumen

Undang-Undang Nomor 39 Tahun 1999 tentang Hak Asasi Manusia

Undang-Undang Nomor 16 Tahun 2006 tentang Perlindungan Saksi dan Korban

Peraturan Pemerintah Nomor 17 tahun 1965 tentang Ketentuan-Ketentuan Pelaksanaan dana Pertanggungan Wajib Kecelakaan Penumpang.

Wagiman, 2006. Refleksi dan Implementasi Hukum Udara: Studi Kasus Pesawat Adam Air, (Jakarta: Jurnal Hukum Bisnis Vol 25) hal. 13.

Whittaker, A.E., \& Robitschek, C (2001). Multidimensional Family Functioning: Predicting Personal Growth Initiative. Journal of Counseling Psychology, 48(4), 420-427. https://doi.org/10.1037/0022-0167.48.4.420

Yin, R. K.2009. Case Study Research: Design and methods (2rd ed) Thousand Oaks, CA: Sage.

Yunas, N.S. 2017. Kebijakan Revitalisasi Sistem Transportasi Publik sebagai Langkah Antisipatif Kemacetan Total di Kota Malang. C osmoGov. Jurnal Ilmu Pemerintahan, 3 (1) 116-126 